IJoLLT Vol. 4, No.2 (September) 2021

eISSN: 2637-0484

\title{
Is it funny? A Case Study of Chinese College Students' Humor Appreciation on English Jokes
}

\author{
JIANG HONGJI (CORRESPONDING AUTHOR) \\ School of Educational Studies \\ Universiti Sains Malaysia \\ hongji@student.usm.my \\ LEONG LAI MEI \\ School of Educational Studies \\ Universiti Sains Malaysia \\ lmleong@usm.my
}

\begin{abstract}
As Schmitz (2002) suggested, it would be useful to conduct experiments in different parts of the world focusing on the appreciation of three types of humor, which are universal or reality-based humor, culture-based humor, and linguistic or word-based humor. This paper aims to investigate the understanding of the three types of humor on Chinese native speakers. 159 Chinese college students finished the online survey by judging the funniness of selected 21 English jokes divided evenly into three types. This study proved Schmitz's proposal that universal jokes are the funniest and cultural jokes are the least funny, which implicated that universal or reality-based humor is easier to be appreciated than the other two types. Moreover, Chinese male college students score higher than female college students in the there types of humor, however, there are no significant differences based on English proficiency, living time abroad, and educational background.
\end{abstract}

Keywords: Chinese students, English humor, funny

Published online: October 2021

To cite this article: Jiang, H., \& Leong, L. M. (2021). Is it funny? A Case Study of Chinese College Students' Humor Appreciation on English Jokes. International Journal of Language, Literacy and Translation 4(2), 18-29. https://doi.org/10.36777/ijollt2021.4.2.043

To link to this article: https://doi.org/10.36777/ijollt2021.4.2.043

This work is licensed under the terms of the Creative Commons Attribution (CC BY) (https://creativecommons.org/licenses/by/4.0/). 


\section{INTRODUCTION}

Over the past few decades, the use of humor in the EFL classroom has been a powerful pedagogical tool for building rapport in the language classroom, and its function in EFL teaching is steadily earning recognition (Bell \& Pomerantz, 2016; Berk, 2000, 2001; Decker, Yao, \& Calo, 2011; Martin, 1998; Wilkins \& Eisenbraun, 2009). However, humor has its specific traits in different cultures, although it is a universal phenomenon. The attitudes and understanding of English humor and its usage of English humor may vary in EFL classrooms in different countries. For example, Jiang, Yue, and Lu (2011) found that Chinese students, compared with American students, held a more negative implicit attitude towards humor. Yue (2011) proposed that Chinese people have traditionally been ambivalent about humor. Chinese tend to value humor but consider themselves to be lacked of humor. Martin and Chen (2007) conducted a study to compare Chinese and Canadian participants by using the Humor Styles Questionnaire (HSQ) and Coping Humor Scale (CHS). Their study found that the Chinese have lower uses of all the four humor styles and coping humor than the Canadians, particularly on aggressive humor.

Humor is both universal and specific. Although humor has a biological fundament implanted in human genes, it also found that cultural norms and individual knowledge play an important role in influencing how it is used in communications, and what topics are considered appropriate for it (Martin, 2007). The scientific classifications shift in the types of humor, with the most straightforward ones characterizing humor loosely into positive and negative types, or appropriate and inappropriate types based on the function that the humor seems to serve (Banas, Dunbar, Rodriguez, \& Liu, 2011; Graesser \& Long, 1988; Martin, 2007; Neuliep, 1991; Schmitz, 2002; Servaité, 2005). For instance, Long and Graesser (1988) classified jokes into ten different categories: (i) nonsense, (ii) social satire, (iii) philosophical, (iv) sexual, (v) hostile, (vi) demeaning to men, (vii) demeaning to women, (viii) ethnic, (ix) sick and (x) scatological. Martin (2007) categorizes three types of humor: (i) jokes, (ii) spontaneous conversational humor, and (iii) accidental or unintentional humor. Servaité (2005) regards that the types of linguistic jokes include phonetics, morphology, semantics, syntax, idiomatic. In this study, the categorization of Schmitz, which meets our research expectations, was used to verify the relationships among different groups of Chinese EFL learners in humor understanding.

In Chinese traditional English classes, teachers often give all students undifferentiated teaching according to the national prescribed teaching syllabus and teaching tasks. Most Chinese teachers are in favor of traditional pedagogical approaches like the grammartranslation method and audio-lingual method that offer teachers maximum control and opportunity to transmit knowledge (Barnard, Richards, \& Rodgers, 2002; Hu, 2002; Wen $\&$ Clément, 2003). Although Chinese students appreciate humor and regard humorous or funny as one of the privileged characteristics of their favored teachers (Wu \& Huang, 2003), the teachers probably do not have the same perception as students (Schaeffer, Epting, Zinn, \& Buskist, 2003), as they seem to emphasize more on teaching content and techniques than rapport with the learners. Since Chinese students do enjoy humorous teaching, then do these students understand or appreciate the English humor? This study is aimed to investigate the understanding of the three types of humor from Chinese college students by rating the funniness of English jokes. 


\section{RESEARCH QUESTIONS}

To verify whether the understanding of English humor elicited by the three types of canned jokes is varied to the different groups of Chinese EFL learners, an explorative study was conducted. According to Schmitz(2002), he categorized humorous discourse into three basic groups: (i) universal or reality-based humor, (ii) culture-based humor, and (iii) linguistic or word-based humor. The 21 canned jokes were collected from the internet and were categorized into three types of groups as universal or reality-based humor $(\mathrm{N}=9)$, culture-based humor $(\mathrm{N}=7)$, and linguistic or word-based humor $(\mathrm{N}=7)$ based on Schmitz's study (Schmitz, 2002). The survey was distributed online and the respondents were asked to rate the funniness of each joke based on their first feelings after reading it. Then, the data were collected and analyzed by SPSS.

Schmitz (2002) believed that the success of the use of humor is due to its neutrality because it is not inappropriate to specific individuals or groups, and the humorous material has to be chosen to fit the linguistic competence of the students. Social and cultural factors play a big part in understanding and appreciating culture-based humor that requires culturespecific knowledge (Bell, 2009; Schmitz, 2002). Schmitz argued that universal humor can be used in all three levels. The linguistic humor would be more effective if introduced when the students are truly intermediate or advanced in their proficiency level. At the advanced level, the three types of humor can be exploited without major problems. Most of the time, students fail to "get" this type of joke owing to a lack of cultural or linguistic knowledge. As Schmitz (2002) suggested, it would be useful to conduct experiments in different parts of the world focusing on the three types of humor. The current study attempted to address the lacuna in this regard and the following research questions were developed:

(1) Which type of English jokes do Chinese students consider funnier?

(2) Do gender, English proficiency, educational background and abroad experience make differences in appreciation of different types of English jokes for Chinese learners?

\section{METHOD}

\section{PARTICIPANTS}

Participants were recruited from three universities via an online survey tool (www.wjx.cn). From an initial sample of 227 who accomplished the full survey, a total of 68 participants were removed for the following reasons: reporting less than 180 seconds of answering the whole survey for 180 seconds is the least time to finish it, and having the same answer of all questions, which aimed to find the respondents who did not treat it seriously. The remaining sample of 159 participants (121 female, 38 male) is 159 Chinese native speakers who all were college students, either in the current studying or graduated (for demographic details, see Table 1). They participated voluntarily and anonymously in the study, and they did not have previous specialized knowledge of humor. This feature guarantees genuine data based on their first feelings after reading those English jokes.

\section{Table 1}


IJoLLT Vol. 4, No.2 (September) 2021

eISSN: 2637-0484

\begin{tabular}{ccc}
\hline Your Gender: & Male & 38 \\
& Female & 121 \\
& Proficiency $(\mathrm{C} 2)$, IELTS exam 8- & 11 \\
& Advanced English $(\mathrm{C} 1)$, IELTS & 20 \\
Your English proficiency: & level 7 & \\
& Upper-Intermediate (B2), IELTS & 33 \\
& levels 5-6 & \\
& Intermediate English (B1), & 47 \\
& IELTS level 4 & 33 \\
Education background: & Elementary English (A2) & 15 \\
& Beginner (A1) & 102 \\
& Arts & 57 \\
Years of English learning: & Science & 11 \\
& $1-3$ & 53 \\
& $4-8$ & 67 \\
Your abroad experience: & $9-15$ & 28 \\
& $16+$ & 119 \\
& 0 & 28 \\
& Less than 6 months & 10
\end{tabular}

\section{INSTRUMENTS}

Twenty one English-written jokes taken from the internet and the three types of jokes were randomly placed in the survey. These jokes were selected as they were short and neutral without offending any specific individuals or groups. The first part of the survey is instructions, such as the introduction of the researcher or research objective, the policy of protecting the private information that is only be used in the research, the time of answering the questionnaire. The final part is demographic information which includes gender, native language, English proficiency, abroad experience, educational background, years of English learning. According to Dörnyei and Taguchi (2009), the factual (or "personal" or "classification") questions will be put at the end because respondents are now ready to look at some interesting questions after reading a long introduction. After conducting reliability statistics in SPSS, the Cronbach's Alpha is 0.935 (Number of items=21), which indicates a high level of internal consistency for this instrument. After the validity analysis, it was found that the KMO value was 0.926, the p-value of Bartlett's Test of Sphericity was 0.000 $(p<0.05)$, indicating the high validity of the questionnaire. And after principal component analysis, it was found that three factors were separated, which were consistent with the three types of jokes expected in this experiment.

Table 2

KMO and Bartlett's Test

\begin{tabular}{lll}
\hline Kaiser-Meyer-Olkin Measure of Sampling Adequacy. & .926 \\
Bartlett's Test of Sphericity & Approx. Chi-Square & 1923.974 \\
& Df & 210 \\
& Sig. & .000 \\
\hline
\end{tabular}




\section{PROCEDURE}

A survey consisting 21 selected jokes based on Schmitz's (2002) categorisation, 7 for universal or reality-based humor, 7 for culture-based humor, and 7 for linguistic or wordbased humor, was used. Each participant was asked to read each joke and rated how funny they are based on their first sensations. When rating these canned jokes, participants were asked to choose using a 6 point scale ( Very funny $=5$; Fairly Funny $=4$; Funny $=3$; Slightly Funny $=2$; Not funny $=1$; Not at all funny $=0$ ). The survey was distributed via the online survey tool, with 68 invalid cases were removed after the data collection and scrutinisation for conscientiousness.

\section{RESULTS}

\section{OVERALL DESCRIPTIONS OF THREE TYPES OF JOKES}

Table 3

The funniness of three types of jokes on Chinese students $(N=159)$

\begin{tabular}{lll}
\hline & Mean & Std. Deviation \\
\hline Universal jokes & 2.7295 & 1.03375 \\
Linguistic jokes & 2.6953 & 1.02600 \\
Cultural jokes & 2.5950 & 1.02569 \\
\hline
\end{tabular}

Universal jokes have the highest average score whereas the lowest score goes to cultural jokes. Through the paired sample T-test, it is found that the cultural jokes with the lowest scores are significantly different from linguistic and universal jokes, with a significant level of $95 \%$. The results of the paired sample T-test are: Cultural-Linguistic $(\mathrm{t}=-2.432, \mathrm{df}=187$, $\mathrm{p}=0.016)$; Cultural-Universal $(\mathrm{t}=-3.198, \mathrm{df}=187, \mathrm{p}=0.002)$; Linguistic-Universal $(\mathrm{t}=-$ $0.719, \mathrm{df}=187, \mathrm{p}=0.473)$. On the other hand, it shows that cultural background jokes are more difficult for foreign language learners to comprehend than the other two types of jokes.

\section{THE CHINESE LEARNERS' FACTORS IN JUDGING FUNNINESS OF ENGLISH JOKES GENDER}

A Sharpie-Wilk's test ( $\mathrm{p}>.05)$ (Shapiro \& Wilk, 1965) and a visual inspection of their histograms, normal Q-Q plots, and box plots showed that the questionnaire scores were not proximately normally distributed for males. The Sharpie-Wilk's tests on males are cultural ( $\mathrm{p}=0.551)$, linguistic $(\mathrm{p}=0.661)$, universal $(\mathrm{p}=0.554)$, although the skewness and kurtosis ratio are in the range of \pm 1.96 , with a skewness of $0.504,0.297,0.376(\mathrm{SE}=0.383)$ and a kurtosis of $0.038,-0.855,-0.930(\mathrm{SE}=0.750)$ for the males and a skewness of $0.007,-0.211$, $-0.162(\mathrm{SE}=0.220)$ and a kurtosis of $-0.193,0.055,-0.299(\mathrm{SE}=0.437)$ for the females. Overall, due to the failure of normal distribution assumption requirement, this study used the Mann-Whitney test as a non-parametric test on gender differences. 
IJoLLT Vol. 4, No.2 (September) 2021

eISSN: 2637-0484

Table 4

Descriptive of male and female scores ${ }^{a}$

\begin{tabular}{lllll}
\hline & & $\mathrm{N}$ & Mean & Std. Deviation \\
\hline Cultural & Male & 38 & 3.1241 & .95467 \\
& Female & 121 & 2.5773 & 1.01676 \\
& Total & 159 & 2.7080 & 1.02631 \\
\hline Linguistic & Male & 38 & 3.2143 & 1.07714 \\
& Female & 121 & 2.6954 & .95635 \\
& Total & 159 & 2.8194 & 1.00778 \\
\hline Universal & Male & 38 & 3.0977 & 1.11654 \\
& Female & 121 & 2.6860 & 1.03026 \\
& Total & 159 & 2.7844 & 1.06261 \\
\hline
\end{tabular}

a. Your native (first) language: $=$ Chinese

Table 5

Test Statistics ${ }^{a, b}$

\begin{tabular}{llll}
\hline & Cultural & Linguistic & Universal \\
\hline Mann-Whitney U & 1641.000 & 1747.500 & 1916.500 \\
Wilcoxon W & 9022.000 & 9128.500 & 9297.500 \\
Z & -2.662 & -2.231 & -1.547 \\
Asymp. Sig. (2-tailed) & .008 & .026 & .122 \\
\hline
\end{tabular}

a. Your native (first) language: $=$ Chinese

b. Grouping Variable: Your Gender:

Through the descriptive statistics tables, it can be seen that the average value of boys in the three categories is higher than that of girls. Then, through the sub-parameter test, the Mann-Whitney Test analysis found that there is a significant difference between Chinese male college students and female college students on Cultural and Linguistic, with a significance level of 0.05 , while the difference is not significant on universal.

\section{ENGLISH PROFICIENCY, LIVING TIME ABROAD, AND EDUCATIONAL BACKGROUND}

Three types of joke judgments are based on English proficiency, living time abroad, and educational background. They are grouped according to the English level, time of living abroad, and educational background. Through the Sharpie-Wilk's test ( $p>.05)$, they are all suitable for parameter testing. ANOVA analysis, and there is no significant difference in the English level of each type of joke cultural $(\mathrm{df}=5, \mathrm{~F}=1.293, \mathrm{P}=0.270)$, linguistic $(\mathrm{df}=5$, $\mathrm{F}=1.527, \mathrm{P}=0.185)$, universal $(\mathrm{df}=5, \mathrm{~F}=1.596, \mathrm{p}=0.164)$ Significance level 0.05. ANOVA analysis, and there is no significant difference in the live time of abroad, cultural $(\mathrm{df}=4$, $\mathrm{F}=1.053, \mathrm{P}=0.382)$, linguistic $(\mathrm{df}=4, \mathrm{~F}=0.433, \mathrm{P}=0.785)$, universal ( $\mathrm{df}=4, \mathrm{~F}=0.612$, $\mathrm{p}=0.655$ ) Significance level 0.05. ANOVA analysis, and the difference between the liberal arts and sciences of each type of joke is not significant, cultural $(\mathrm{df}=1, \mathrm{~F}=1.050, \mathrm{P}=0.307)$, linguistic $(\mathrm{df}=1, \mathrm{~F}=0.242, \mathrm{P}=0.623)$, universal $(\mathrm{df}=1, \mathrm{~F}=0.177, \mathrm{p}=0.675)$ Significance level 0.05 
IJoLLT Vol. 4, No.2 (September) 2021

eISSN: 2637-0484

Table 6

Descriptives $^{a}$

\begin{tabular}{lllll}
\hline & & $\mathrm{N}$ & Mean & Std. Deviation \\
\hline Cultural & $1-3$ & 11 & 3.2597 & 1.32144 \\
& $4-8$ & 53 & 2.9057 & .97615 \\
& $9-15$ & 67 & 2.6311 & .97879 \\
& $16+$ & 28 & 2.3010 & .97616 \\
& Total & 159 & 2.7080 & 1.02631 \\
\hline Linguistic & $1-3$ & 11 & 3.2468 & 1.26021 \\
& $4-8$ & 53 & 2.9946 & .96198 \\
& $9-15$ & 67 & 2.7463 & .99062 \\
& $16+$ & 28 & 2.4949 & .95751 \\
& Total & 159 & 2.8194 & 1.00778 \\
\hline Universal & $1-3$ & 11 & 3.1818 & 1.33873 \\
& $4-8$ & 53 & 3.1294 & .93814 \\
& $9-15$ & 67 & 2.6631 & 1.04260 \\
& $16+$ & 28 & 2.2653 & .98876 \\
& Total & 159 & 2.7844 & 1.06261 \\
\hline
\end{tabular}

a. Your native (first) language: $=$ Chinese

Interestingly, the longer you study English, the lower your score is. ANOVA analysis shows that there are significant differences between cultural and general jokes, cultural $(\mathrm{df}=3, \mathrm{~F}=3.463, \mathrm{P}=0.018)$, linguistic $(\mathrm{df}=3, \mathrm{~F}=2.336, \mathrm{P}=0.076)$, universal $(\mathrm{df}=3, \mathrm{~F}=5.292$, $\mathrm{p}=0.002)$ Significance level 0.05 .

The longer Chinese English learners study, the lower their scores. It can be explained that one is that people who have studied English for a long time have seen a lot of jokes, and the other is that, people who have studied for a long time have higher English proficiency. For example, those who are native English speakers have lower scores.

\section{THE DIFFERENCE BETWEEN CHINESE AND ENGLISH SPEAKERS IN THREE TYPES OF JOKES}

The purpose of this study is not to compare the differences in the perception of jokes between native Chinese speakers and native English speakers. However, in order to have a reference object to verify whether it is the reason for the selection or classification of jokes, the questionnaire was posted online (via language lover community) in which 29 English native speakers participated namely 23 from the United States, 3 from Canada, 1 from Ireland, 1 from Australia, and 1 from the UK.

The analysis of the degree of funniness in the three types of jokes between Chinese and English students showed they have the same perception. A Sharpie-Wilk's test ( $\mathrm{p}>.05)$ (Shapiro \& Wilk, 1965) and a visual inspection of their histograms, normal Q-Q plots, and box plots showed that the questionnaire scores were approximately normally distributed for Chinese and English students. The Sharpie-Wilk's tests on Chinese are cultural $(\mathrm{p}=0.135)$, linguistic $(\mathrm{p}=0.240)$, universal $(\mathrm{p}=0.267)$, on English are cultural $(\mathrm{p}=0.755)$, linguistic $(\mathrm{p}=0.948)$, universal $(\mathrm{p}=0.163)$.

\section{Table 7}

The difference between Chinese and English speakers in three types of jokes

$\mathrm{N} \quad$ Mean $\quad$ d. Deviation


IJoLLT Vol. 4, No.2 (September) 2021

eISSN: 2637-0484

\begin{tabular}{|c|c|c|c|c|}
\hline \multirow{3}{*}{ aiversal } & Chinese students & 159 &. .7295 & 1.03375 \\
\hline & English students & 29 & $\therefore .4286$ & .80902 \\
\hline & Total & 188 & $\therefore .7295$ & 1.03375 \\
\hline \multirow{3}{*}{ nguistic } & Chinese students & 159 &. .6953 & 1.02600 \\
\hline & English students & 29 & $\therefore .0148$ & .85573 \\
\hline & Total & 188 & $\therefore .6953$ & 1.02600 \\
\hline \multirow{3}{*}{ Cultural } & Chinese students & 159 &. .5950 & 1.02569 \\
\hline & English students & 29 & .9754 & .78253 \\
\hline & Total & 188 & $\therefore .5950$ & 1.02569 \\
\hline
\end{tabular}

Through descriptive statistics, it is found that in each type of joke, Chinese students score higher than English, and native English speakers think that each type is less funny than Chinese students did. The similarity is that they have the same perception of the funniness of each type of joke. They both think universal jokes are the funniest, and cultural jokes are the least funny, and native English speakers have the lowest score for cultural jokes of 1.9754 .

Participant A: Honestly, the funniest jokes were the ones that had very little to do with puns. Most of them would pass with an eye roll, and a groan, but the one with the shower curtain legit made me laugh.

Participant B: Ifeel like the teabag one may go over some American's heads because I'd say most of us don't follow the World Cup. Also, the shower curtain one was really good. I had to think about the teabag one for a long time before I figured it out.

Participant C: Yeah, this American didn't get the teabag joke at all.

Due to the convenience of the language community, several participants have formed a discussion, and this study extracts feedback from three of them. This feedback also proves that cultural jokes are not as funny as universal jokes. For example, they regard that 'shower curtain' joke (U6) as funny, which is a universal joke, but the 'teabag' joke (C6) is not funny and even takes a long time to understand as an American.

\section{DISCUSSION}

Universal jokes have the highest average score and the lowest score is cultural jokes. Cultural jokes seem hard to understand which corresponds with the argument of Schmitz's research. There are two potential reasons for explaining why universal jokes are funniest. One is that the English proficiency of Chinese students is not far enough to understand linguistic and cultural jokes, which leads to low scores for these two types of jokes. Second, universal jokes are indeed the funniest among the three types, so Chinese students score the highest in the universal category.

When physics meets Star Wars: May the net force be with you! (C4)

People who are growing up in an English-speaking culture would more likely appreciate the joke of "star wars", but not all foreign language learners will understand it due to a lack of specific cultural knowledge. From the data analysis, it can be seen that universal jokes, that is, jokes without language and cultural background, are more fun. When interpreting linguistic and cultural jokes, it takes longer for the brain to understand and process, which 
is far away from the reader's daily life background and is not easy to resonate with. As Davis (2011) points out, different cultures and times have evolved a range of protocols and social conventions for channeling and containing humor-making and humor-appreciation. A good example of a linguistic-based joke, quite difficult for many learners is the joke (6) below:

What is another word for Thesaurus? (L1)

This joke demands a great deal of lexical competence on the part of learners for they have to cope with the play on the word Thesaurus and native speakers of languages that do not have this type of humor fail to find this type of joke to be amusing.

A clear limitation of this study is that the jokes selected from the internet may be outdated. Some jokes may not be funny because they appeared a long time ago and are known by many, and some cultural jokes may not be funny as the readers who are comprehending it is not in that context. According to Schmitz (2002), EFL learners need higher English proficiency to understand cultural and linguistic humor. From the sample of this study, most Chinese EFL learners are not advanced learners, hence the reason that they think cultural jokes are not humorous may be due to their low English proficiency. However, English native speakers also regard the cultural jokes as not funny, so we may conclude that Chinese EFL students' perceptions of the funniness of jokes are not related to their language proficiency, and the universal jokes are funnier than cultural jokes naturally. In the future study, it would be more plausible if more sample numbers and data collecting methods such as interviews are added.

\section{CONCLUSION}

In conclusion, this study proved Schmitz's proposal that universal jokes are the funniest and cultural jokes are the least funny, which implicated that universal or reality-based humor is easier to be appreciated than the other two types. Therefore, teachers who would like to try to use English jokes in their class need to be aware of the students' appreciation among the different types of jokes. The universal humor could be used for English language beginners, but the other types of humor are also encouraged to use for advanced learners. Moreover, the study indicated that Chinese male college students appreciate English humor more than female college students, but the differences in humor appreciation based on English proficiency, living time abroad, and educational background have no significance. Due to the number of male participants was restricted, this finding ought to be generalized with caution. Future studies should include more participants of both genders and explore the reasons behind it. Last but not least, as Schmitz proposed, future research should also replicate the same or similar study in other cultures or areas while native English speakers as a control group should be served as well. 


\section{REFERENCES}

Banas, J. A., Dunbar, N., Rodriguez, D., \& Liu, S. J. (2011). A review of humor in educational settings: Four decades of research. Communication Education, 60(1), 115-144. https://doi.org/10.1080/03634523.2010.496867

Barnard, R., Richards, J. C., \& Rodgers, T. S. (2002). Approaches and Methods in Language Teaching. TESOL Quarterly, 36(4), 636. https://doi.org/10.2307/3588247

Bell, N. D. (2009). Learning about and through humor in the second language classroom. Language Teaching Research, 13(3), 241-258. https://doi.org/10.1177/1362168809104697

Bell, N. D., \& Pomerantz, A. (2016). Humor in the Classroom: a guide for language teachers and educational researchers. Routledge. https://doi.org/10.1080/00098655.1964.11476050

Berk, R. A. (2000). Does Humor in Course Tests Reduce Anxiety and Improve Performance? College Teaching, 48(4), 151-158. https://doi.org/10.1080/87567550009595834

Berk, R. A. (2001). The active ingredients in humor: Psychophysiological benefits and risks for older adults. Educational Gerontology, 27(3-4), 323-339. https://doi.org/10.1080/036012701750195021

Chen, G. H., \& Martin, R. A. (2007). A comparison of humor styles, coping humor, and mental health between Chinese and Canadian university students. Humor, 20(3), 215-234. https://doi.org/10.1515/HUMOR.2007.011

Davis, J. M., \& Chey, J. (2011). Humour in Chinese life and letters: Classical and traditional approaches. In Hong Kong University Press (Vol. 1).

Decker, W., Yao, H., \& Calo, T. (2011). Humor, Gender, and Perceived Leader Effectiveness in China. SAM Advanced Management Journal, 76(1), 43.

Dörnyei, Z., \& Taguchi, T. (2009). Questionnaires in Second Language Research: Construction, Administration, and Processing. In Routledge. https://doi.org/10.1525/jlin.2006.16.2.294

Graesser, A. C., \& Long, D. (1988). Wit and Humor in Discourse Processing. Discourse Processes, 11(1), 35-60. https://doi.org/10.1080/01638538809544690

$\mathrm{Hu}$, G. (2002). Potential cultural resistance to pedagogical imports: The case of communicative language teaching in china. Language, Culture and Curriculum, 15(2), 93-105. https://doi.org/10.1080/07908310208666636

Jiang, F., Yue, X. D., \& Lu, S. (2011). Different attitudes toward humor between Chinese and American students: Evidence from the Implicit Association Test. Psychological Reports, 109(1), 99-107. https://doi.org/10.2466/09.17.21.PR0.109.4.99-107

Martin, R. A. (1998). Approaches to the sense of humor: A historical review Humor and sense of humor. The Sense of Humor: Explorations of a Personality Characteristic, 15. https://doi.org/10.1515/9783110804607.15

Martin, R. A. (2007). The Psychology of Humor. The Psychology of Humor. https://doi.org/10.1016/B978-0-12-372564-6.X5017-5

Neuliep, J. W. (1991). An examination of the content of high school teachers' humor in the classroom and the development of an inductively derived taxonomy of classroom 
humor. Communication Education, 40(4), 343-355. https://doi.org/10.1080/03634529109378859

Schaeffer, G., Epting, K., Zinn, T., \& Buskist, W. (2003). Student and faculty perceptions of effective teaching: A successful replication. Teaching of Psychology, 30(2), 133136.

Schmitz, J. R. (2002). Humor as a pedagogical tool in foreign language and translation courses. Humor, 15(1), 89-113. https://doi.org/10.1515/humr.2002.007

Servaité, L. (2005). The anatomy of a joke. Tiltai: Humanitariniai Ir Socialiniai Mokslai, $4,81-85$.

Shapiro, S. S., \& Wilk, M. B. (1965). An analysis of variance test for normality (complete samples). Biometrika, 52(3/4), 591-611. https://doi.org/10.1093/biomet/52.3-4.591

Wen, W. P., \& Clément, R. (2003). A chinese conceptualisation of willingness to communicate in esl. Language, Culture and Curriculum, 16(1), 18-38. https://doi.org/10.1080/07908310308666654

Wilkins, J., \& Eisenbraun, A. J. (2009). Humor theories and the physiological benefits of laughter. Advances in Mind-Body Medicine, 24(2), 8-12.

Wu, G., \& Huang, X. (2003). Dangdai zhongxuesheng xiai de jiaoshi renge tezheng yanjiu [A study on the personality characteristics of teachers favored by Middle School Students]. Educational Research and Experiment, 4.

Yue, X. D. (2011). The Chinese ambivalence to humor: Views from undergraduates in Hong Kong and China. Humor, 24(4), 463-480. https://doi.org/10.1515/HUMR.2011.026 


\section{APPENDIX \\ UNDERSTANDING OF ENGLISH JOKES SURVEY}

The primary purpose of this survey is to investigate the understanding of English jokes from ESL (English as a second language) or EFL students. This is not a test so there are no "right" or "wrong" answers and you do not even have to write your name on it. Please read each item carefully, and rate them according to your actual sensations. Thank you!

Please choose the degree of funniness of each joke based on your first feeling. 阅读以下英文笑话，根据自己的第一感觉，选择你认为该笑话的好笑程度。 Very funny 非常好笑 > Fairly Funny 很好笑> Funny 一般 > Slightly Funny 有一点> Not funny 不好笑 > Not at all funny 完全不好笑

Vacation begins when Dad says. "I know a shortcut"! (U1)

Energizer Bunny arrested... charged with battery. (C1)

I don't suffer from insanity... I enjoy every minute of it. (U2)

Nothing is fool-proof to a sufficiently talented fool. (U3)

Bills travel through the mail at twice the speed of checks. (C2)

What is another word for Thesaurus? (L1)

And out of the night came the terrible scream, "who puts the sand in the Vaseline?" (C3)

When physics meets Star Wars: May the net force be with you! (C4)

Q: What do you call a guy that sits on your doorstep?

A: A Matt. (L2)

What disasters would happen if a waiter dropped a plate of turkey?

The downfall of Greece, the overthrow of Turkey and the break up of China. (L3)

Borrow money from a pessimist--They don't expect it back. (U4)

A man said his credit card was stolen but he decided not to report it because the thief was spending less than his wife did. (U5)

What did the chef name his son?

Stu (C5)

"Do you know the difference between toilet paper and a shower curtain?"

"No..."

"Hey, everybody! I found the guy!" (U6)

Police officer: "How high are you?"

Pothead: "No officer, its "Hi. How are you?" (L4)

I'm going to stand outside. So if anyone asks, I am outstanding. (L5)

Q: What is the difference between a teabag and England?

A: The tea bag stays in the cup longer! (C6)

Customer: "Waiter, do you serve crabs?"

Waiter: "Please sit down Sir, We serve everyone." (L6)

Customer: Gave me a hotdog.

Waiter: With pleasure.

Customer: No, with mustard. (U7)

America is a country which produces citizens who will cross the ocean to fight for democracy but won't cross the street to vote. (C7)

Sometimes people with a lot of cents have little sense. (L7) 